Portland State University

PDXScholar

1979

\title{
Modification of the Record-Keeping System of a Community Mental Health Agency
}

\author{
Karen Knight \\ Portland State Universtiy \\ Christine Neilsen \\ Portland State Universtiy \\ Craig Schreiter \\ Portland State University
}

Follow this and additional works at: https://pdxscholar.library.pdx.edu/open_access_etds

Part of the Social Work Commons

Let us know how access to this document benefits you.

\section{Recommended Citation}

Knight, Karen; Neilsen, Christine; and Schreiter, Craig, "Modification of the Record-Keeping System of a Community Mental Health Agency" (1979). Dissertations and Theses. Paper 2648.

https://doi.org/10.15760/etd.2644

This Thesis is brought to you for free and open access. It has been accepted for inclusion in Dissertations and Theses by an authorized administrator of PDXScholar. Please contact us if we can make this document more accessible: pdxscholar@pdx.edu. 


\title{
MODIFICATION OF THE RECORD-KEEPING SYSTYM
}

OF A COMMUNITY MENTAL HEALTH AGENCY

\author{
by \\ KAREN KNIGHT \\ CHRISTINE NEIISEN \\ CRAIG SCHREITER
}
A practicum submitted in partial fulfillment of the requirements for the degree of
MASTER OF SOCIAL WORK

Portland State University

1979 


$$
\text { - }
$$


PROLOGUE

The project described in this report was selected to fulfill the graduate practicum required by the School of Social Work, Portland State University. A group of three students from PSU worked on this project. Two had field placements at Salem Area Family Counseling and the third had previously been employed by the agency. We want to thank members of Salem Area Family Counseling for their invitation to involve their agency as a project focus. Agency staff members were avallable and interested in the project process and results.

We also wish to acknowledge those individuals who shared the record-keeping systems of their agencies, specifically, Leigh Anderson, Mlahan Center for Mental Health; Jess Armas, Community Counseling; Terxi Swan, Yamhill County Mental Health Agency; Jim Hardison, State Mental Health Division; and Jenny Steward, Iutheran Family Services.

Our special appreciation is addressed to Nancy Koroloff, our advisor during this project. She provided much guidance and remained supportive throughout its duration. 
TABLE OF CONTENTS

PAGE

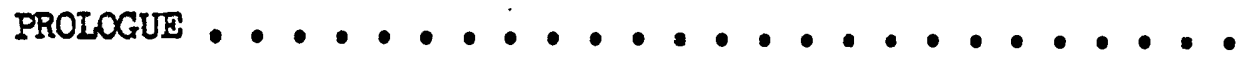

i11

LIST OF FIGURES $\bullet \bullet \bullet \bullet \bullet \bullet \bullet \bullet \bullet \bullet \bullet \bullet \bullet \bullet \bullet \bullet \bullet \bullet \bullet \bullet \bullet$

CHAPTER

I INTRODUCTION $\bullet \cdot \bullet \cdot \bullet \cdot \bullet \cdot \bullet \cdot \bullet \cdot \bullet \bullet \cdot \bullet \cdot$

Project Overvier .............

Context Within Which the Project Occurred.

Organization of the Report .......

II FOCUSING $\bullet \bullet \bullet \bullet \bullet \bullet \bullet \bullet \bullet \bullet \bullet \bullet \bullet \bullet \bullet \bullet \bullet \bullet \bullet$

III RESEARCHING $\bullet \bullet \bullet \bullet \bullet \bullet \bullet \bullet \bullet \bullet \bullet \bullet \bullet \bullet \bullet \bullet \bullet$

Salem Area Family Counseling Service Information System $\ldots . . . . . . . .$.

Information Systems at Other Agencies ...

Iiterature Search . • • • • • • •

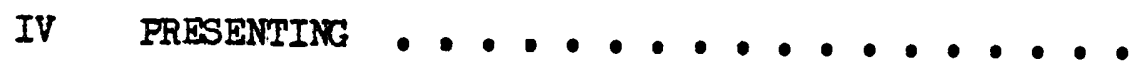

$v$ DESIGN, IMPLEMENTATION AND FOLLOW-UP • • •.

30

vI CONCLUSION $\bullet \bullet \cdot \bullet \cdot \bullet \cdot \bullet \bullet \bullet \bullet \bullet \bullet \bullet \bullet \bullet \bullet \bullet$

40

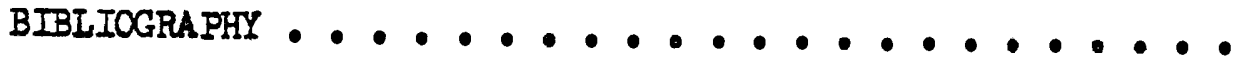


LIST OF FIGURES

FIGURE

PAGE

1. Organizational Chart of Salem Area Family

Counseling ................... . 3

2. Information System, November, 1977 . . . . . 10

3. Application Form - . . . . - . . . . . . 11

4. Data Gathered at Salem Area Family Counseling.

November, 1977 ............. 14

5. Developmental Contimuum of Record-Keeping Changes - - 23

6. Benefits and Problems of Options for Evaluative

Activity ................... 28

7. Face Sheet . . . . . . . . . . . . 33

8. Intake and Plan . . . . . . . . . . . $3^{5}$ 
CHAPTER I

INTRODUCTION

\section{Project Overview}

In recent years the soclal service fleld has incorporated prom gram evaluation. In this time of accountability, funding sources want to know what they are buying. As they respond to this re-quirement, agencies often discover that they have been Iiving with archaic record-keeping systems. Systens which are cumbersome, or do not collect needed information have become the focus for change.

Originally, the agency requested the authors to conduct an opinion survey among counseling clients regarding the services given then. However, questions about the utility of such a survey and discussions with the progran director and executive director, prompted the authors to broaden this goal. Ultimately, the authors and the agency representatives contracted for the improvement of the agency record-keeping systen. This system could then be expanded to collect and produce process and outcome information. A brief description of the setting in which the project took place follows. Context Within Which the Project Occurred

The context overview includes, first, information about the agency, Salen Area Fantly Counseling Service (SAFCS), second, about the catchment area from which it draws clients, and third, about the people it serves. The tine perspective from which this is vritten 
1s November, 1977, when the project began.

Salem Area Fantly Counseling Service 1s a small, private, nonprofit agency, located within walking distance of downtown Salen.

It was begun in 1965 by a group of citizens, both professional and lay people, who felt that Salem needed a non-denominational alternat1ve to other counseling services avallable within the city. Financing came fron donations, Untted Way, and cllent fees. The agency has expanded services since that time, and now offers programs in two distinct areas, counseling for individuals, couples, and families (the area in which the project took place); and a homomaker service. The two progran areas funtion independently of one another, with the only duplication of staff being provided by the executive director and the program director, who oversee both areas. The staffing pattern in the counseling program in November, 1977 is shown in Figure 1. Although the pattern appears hierarchical, informally the process is familial. The executive director, the program director, and one of the clexical staff had been employed by the agency for several years. The remainder of the staff had been with the agency less than six months. There were both part-time and fullt1ne employees.

The goal of the services provided in the counseling program at that tine was

to enhance the mertal and emotlonal well-belng of persons suffering stress by providing professionsl counseling services. The purpose of counseling will be to alleviate and/or eltminate such stress (Untted Way Budget; 1978).

The theoretical base from which this service is offered relies strongly on transactional analysis as a nethod of diagnosis, a treat- 
Figure 1. Organizational chart of Family Counseling Services

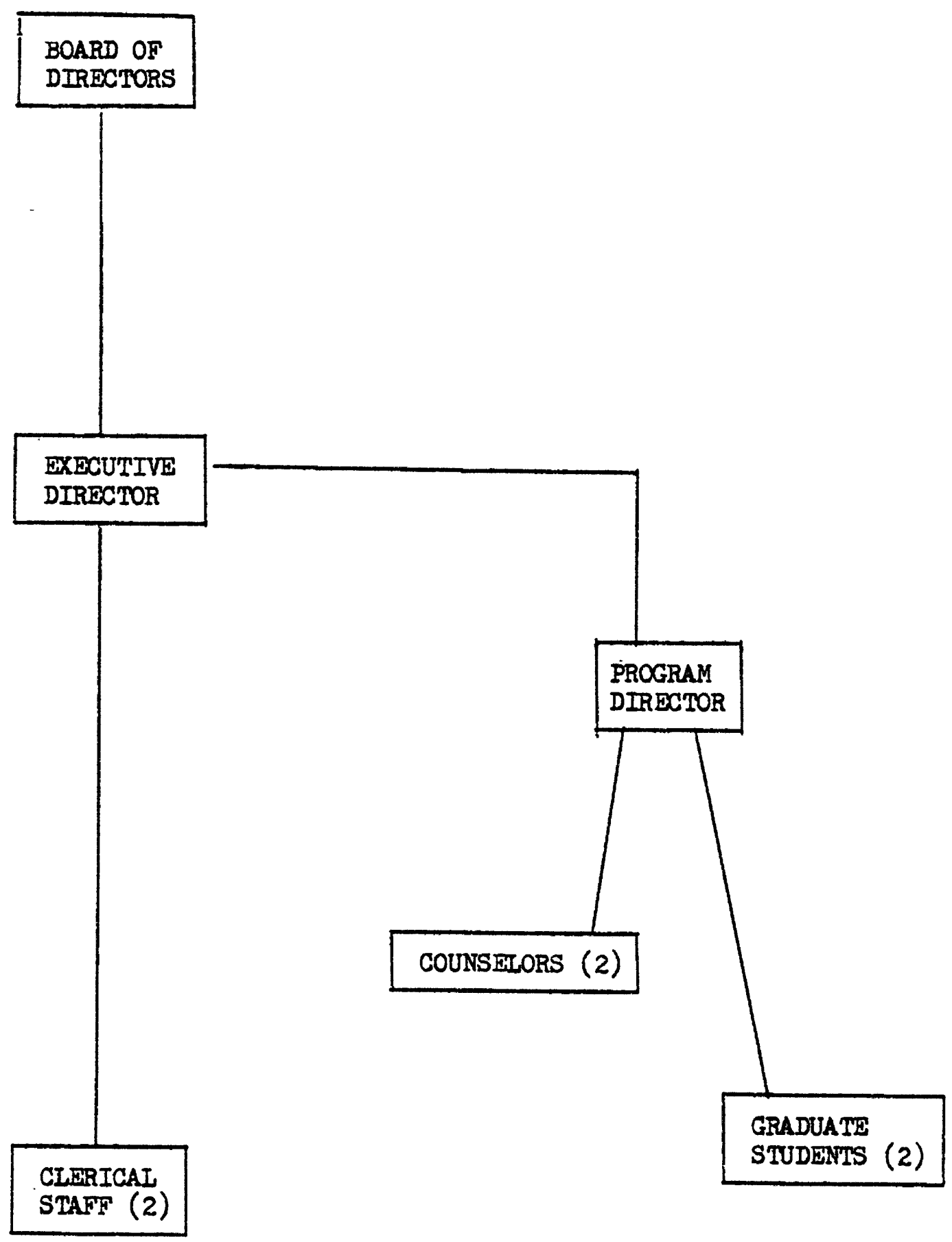


ment strategy, and a comonly shared jargon. This perspective on human problems does not support direct intervention in a client's environment, but rather supports helping the individual to increasIngly take responsibility for the chotces which affect his or her 11fe. The client is not seen as a passive reciplent of circumstances, but as an active participant who has the power to mold his or her own Iifestyle (James and Jongenard, 1973).

Staff at the agency are not Iimited to transactional analysis, and alternative approaches vary with the individual therapist. A commonality of all is individual, rather than environmental, change. From this perspective, counseling staff offer individual, couple, family and group therapy. Clients are usually seen on a reekly or bi-weekly basis.

Funding for this service cones from the United Way, the City of Salen, Marion County, and fees generated fron a sliding fee scale. Each of the funding sources designates a specific clientele, purchases a certain mumber of hours of service, and requires particular descriptive information:

The catchment area fron which agency clients are drawn is conposed of Marion, Polk, and Yanhill counties. It has Salea as 1 ts major popelation center. Thirty-six percent of the 220,000 residents In the tri-county area Iive within the city Iimits. There is a wide cross-section of education, income, and employment. The city of Salem itself ranks within the top three in the state for mumber of persons receiving public assistance, yet also claims 24,000 governnent employees. The aree has informally been. dubbed "conservative". 
(Statistical Data Base, 1978).

Descriptive information about the exact nature of clients served in November, 1977, was not easily avaflable. Observation suggested that they are predominantiy female, adult, individuals. A large proportion of clients were known to reside within the city limits.

The interplay of these elements - the existence of the agency within a conservative community environment; recent staff turnover; well-defined, shared, theoretical perspective on human problems; multiple funding sources - formed a complex context within which the project occurred.

\section{Organization of the Report}

The following report will describe the dexivation of the project objective and the process involved in its implementation. The resulting record-keeping system will also be described and compared to the system prior to the project. Four phases of activity are discussed. The first is clarification of focus. The second is examination of the current information systen, researching alternatives and surveying relevant literature. The third is formulation and presentation of the relevant parts of the information gathered to the staff of SAFCS for decision-making. The fourth is 1mplementation and following up that desision. A description of those phases of activity follous. 
CHAPTER II

FOCUSING

The interval between the original request for an opinion survey and the finalized project objective was spent gathering information and clarlfying agency needs. Initial investigation of the agency suggested that records were naintained, but data was difficult to collect, and much of what was collected was not utilized. The authors based this assessment upon unstructured observation and their own use of the client files which showed the records kept to be inadequate in accurately describing ellents served.

Since the authors questioned the ability of an opinion survey to produce useful information without an adequate description of clients, nodlfication in the basic descriptive information available seemed desirable.

Discussions with the agency staff and a respected consultant In program evaluation encouraged the authors to expand the purpose of the project. Further discussions with the executive director and program director about their information needs clarified the focus. Prominent among mangement concerns was accountability to external funding agencies. Fach funding agency requested frequent reports about who SAFCS served. These requests placed special demands upon SAFCS's record-keeping system.

While the pagement expressed the political appeal of an opinion 
survey, they noted that the results would have questionable impact upon decisionmakers (Hagedorn, 1976, p. 232). Such surveys are consistently blased in a positive direction and because they do not specify input, they are seldon used. UItimately, they hoped to generate a statement indicating the value of their service to SAFCS clients which could serve to support requests for increased funds for program expansion. The focus of the project then became to prosent options from which SAFCS could pursue evaluative activity. Though open to all options, the authors were charged with the task of recomending a system that the agency staff would implement. This Invited evaluative activities that were not nerely good approaches to evaluation, but feasible as well. Unique features of the agency which influenced this were its informal structure and decisionmaking; its philosophy and approach toward cllents; resources in time, staff, and money; and the existing approach to evaluative activity. It was essential to gain a comprehensive understanding of SAFCS in order to develop an approach to evaluation. 
CHAPTER III

RESEARCHING

The second phase of the project consisted of a detalled examination of SAFCS information systen, gathering information from other agencies with sinilar functions, and a search of relevant I1terature.

\section{Asencr Information System}

For the purpose of study, the information system was viewed fros three aspects: the means used to collect the data; the operation of the system; and the content of the data collected. Several tasks were performed to arrive at a thorough picture of the information system, these reres

1. An appraisal of data that was both available at the agency and pertinent to clients.

2. An examination of all files on current cllents.

3. Interviews of all staff from the secretary to the director about any independent or private records kept. The interviews inquired into the staff understanding about the workings of the information systew.

4. An inspection of the fee and billing system.

5. An examination of representative samples of the reports made to organizations providing funds to SAFCS.

The data collection system overvien is graphically presented in 
Figure 2.

Th1s information 18 presented in flow chart fashion to make clear the operation of the record-keeping system and the relationship of Its components. The neans of collecting data vere divided into the following components.

Appointment Book: All appointments for agency staff were recorded in the large book, noting the name of the client and therapist. A notation adjecent to the name indicated the appointment status "cc" called and cancelled; "ns" - no show. A valting list was maintalned on the front sheet of each month's record.

The appointment book served to verify previous contact with clients: It also was used as a communication network for staff. For Instance, a meeting might be called by merely blocking out a specified hour for all staff by writing in the page "staffing".

Application Form: (a reduced copy is presented in Fioure 3) The upper portion of this form was completed by the alient on the first appointment with help from the receptionist. The type of information gathered remained essentlally unchanged during the client's contact with the agency, e.g., name, highest grade completed, birth date, address:

Fees rere based upon the information given by the client and the fees were recorded upon the application form. Billing information and any demographic information was gathered from the top portion of this sheet. In the lower portion of the application form the therapist recorded the client situation, cllent gogls, diagnosis, mode of intervention, history, etc. Contimous recoriing could begin in this 
Fisure 2. Information System, November 1977

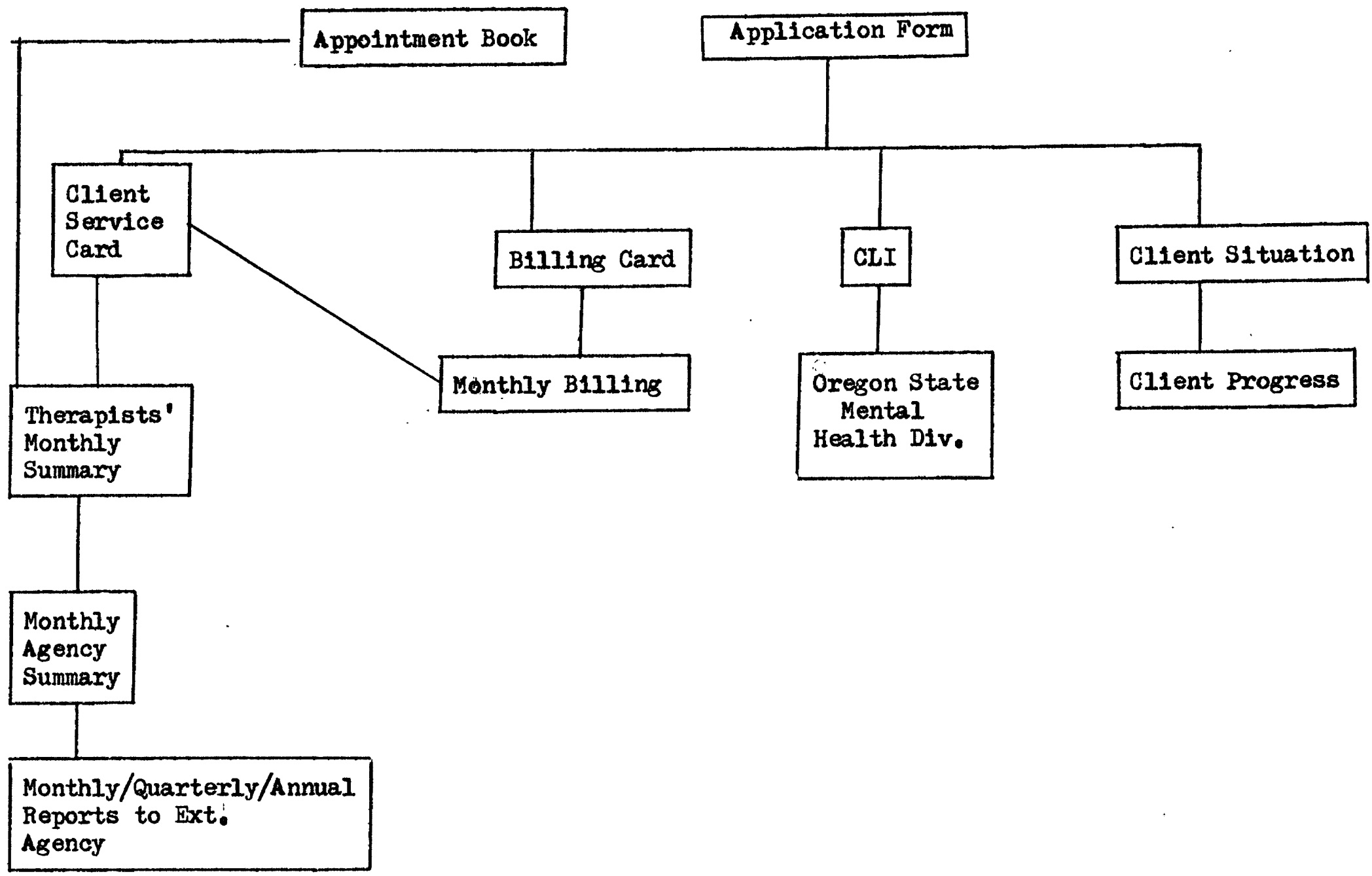




\section{Figure 3. Application Form (reduction)}




section or on the reverse side of the sheet. The manner in which this section was completed, and its content, were highly individualized. Questions located in the lower thind of the pege were not filled out.

CLI: This mult1-page form was used to report to the State Mental Health Division. The state information system was aubomated. The form collected demographic information on each client while coded in such a way to insure the client's right to confidentiality. At the time of opening and closing, each case therapist who completed the entire form was asked to mamerically rank the severity of possible presenting problem on a scale of 1-4. For instance, maber 3 by alcoholism rould indicate a high degree of involvement with alcohol for this client. All information was combined at the county level. SAFCS had no access to this statewide system of mental health information. Billing Cand: Information was taken from the application form pertinent to the process of sending a bill, e.g., address. This card was maintained by the receptionist who was responsible for blling clients. .

Client Service Card, Each therapist maintained a $3 \times 5$ cand for each cllent contact they had made during a month. The information collected was mane, length of the contact, and nature of the contact. Client Monthly Activity Report: Information taken.from the individual service caris was compiled monthly for each client and recorded on one page of the therapist's $10 \mathrm{~g}$ book. Other information gathered from the application forw, either upper or lower portion, night include such social indicator information as whether the client was a ferale head of a household. 
Arency Monthly Activity Repoxt: The executive director and the receptionist aggregated the client monthly activity reports. The areas of content were based upon the latest request for Information from the funding agencies. Some itens included in this report were: sumber of new and contimued clients, ractal background, below poverty level.

The itens found through these means of collection were categorized by the authors into two general typesi demographic and client situation. In Flgure 4 is a comprehensive listing of each iten type gathered at the time of the initial survey. The designations of Type I and II correspond to the demographic and client situation data respectively. These designations were developed to illustrate to the staff the distinction among the various data collected.

In practice the opecation of this information system presented many barriers to collection, storage and retrival. Describing these problems along the division of Type I and II categories (as designated in Figure 4) parallels the planning and implementing of modifications adopted in later phases of the project.

The Type I data listing demographic itens were taken exclusively from the application form. This retrieval process presented several difficulties for the staff as they completed reports. The format of the application form did not fit the needs of staff for gathering Information. For Instance, if it became necessary to report the number of cllents of $65+$ years of age, the lack of birthdate and age information became an insurmountable obstacle.

The language used on the form, and the layout of questions on the page, contributed to difficulties for clients in understanding the 
Flgure 4. Data gathered at Salem area Family Counseling Service November, 1977

Type Is Demographic

Name
Address
Telephone namber
Source of appointment
Birthdate
Birth place
Race
Religion
Citizenship
Resident Status
Education
Other household nembers,
ages
Occuption
Pmployer
Incone
Marriage Date
Marital Status
Inconing Status

Counselor

Hours spent with each client Hours spent with each type Hours cancelled Hours for crisis Hours spent in counseling support activities

Sources of Funding, Amounts

Low Income Clients Female-headed households Block Grant Area Clients
Type II: Assessment and Process Related

Some form of intake assessment CLI Assessment: (kept on State Mental Health CIlents)

Rankings of Involvement:

Suictde

Aggression

Job Involvement

School Involvement

Homemaking

Family

Anti-Social

Friend or peer

Thought Process

Physical Symptoms

Affect

Marital

Drug

Alcohol

Termination Assessments

Coded disposition showing improve= ments/or nontmprovement

Assessment on each of the above areas showing improvement or nonimprovement

Random progress notes

Termination dates, posstble summary statenent 
form. The receptionist reported clients frequently requested assistance to complete the application form because they did not know how to interpret some of the questions. One such question was an inquiry into the person or agency who referred the client to SAFCS, stated as "source of application, "It can be noted that the intent of the question is ambiguous. The format of the request for information about education and employment seemed to contribute to clients' incomplete responses in these areas.

The information categorized as Type II, assessment and process related data, was collected in the lower section of the application form where blank space allowed for therapists to describe in an unprescribed manner the clients' situation, presenting problem, plan or approach, and the cllents' responses to the intervention. The small amount of room provided,allowed for only minimal recording. The lack of structure provided for in the space contributed to the problem of nonuniform collection of data.

The survey of the client files revealed that the therapists had not included notations about the different facets of contact with clients in any consistent, comparable or comprehensive manner. The areas addressed in each file varied. For example, it was the practice of the agency to insist upon the clients' involvement in setting the direction of therapy. Yet information about this involvement was recorded only sporadically.

The language also contributed to this lack of clarity of recorded information. The terminology employed at SAFCS to depict clients' circumstances orlginated from the staff's' shared conceptual framework, Transactional Analysis. This theory base does provide a diegnostic 
nosology for study and analysis. However, in clinical practice the staff used the terminology as a shorthand. The descriptions the staff gave of the circumstances of clients were often a few sentences in length and sometimes merely a few words or diagrams. This practice by staff left the reader with the experience of no objective comparable description from one case to another, from one point in time in a client's contact with the agency to another, and from one therapist to another. Also, frequently lacking in the client file was information which specified the mode of therapy the client was engaged in, even though several modes were avallable and clients did transfer from one to another.

As mentioned earlier, the agency staff had no agreed upon procedures for recording elther at intake, or for the maintenance of a contimuing record of client progress while in therapy at the agency. The findings of the survey of client files were that recording was not done at regular reporting periods and in many cases had not been done from the time of intake.

In summary, the examination of available data and practices relating to collecting data suggest that the main problem areas were: lack of uniform data; an application form that was difficult to complete; inaccuracy in information on the application form; lack of regular reporting periods about client progress; insufficient description of clients' circumstances; and inconsistent coverage of various aspects of clients' situation.

\section{Other Agencies}

In order to gather information about procedures for maintaining 
data about clients in use at other mental health agencies, interviews were scheduled at Yamhill County Mental Health Clinic in McMinnville, and Elahan Mental Health Clinic in Vancouver, which had broad data bases, and client goal-oriented recording processes; at Lutheran Family Services, in Portland, which had a comparable theoretical base for treatment; and at Community Counseling Service in Salen, the only other agency in Salem comparable in service provision to SAFCS. The interviews included examInation of dummy client files, data tallying procedures, and conversations with clerical, counseling, and, when employed, evaluation staff. Some tentative conclusions based on input from staff at these agencles, and examination of their procedures were:

1. The type of demographic data gathered on clients was essentially the same at all agencles, including SAFCS. However, different agencies regularly tallied different items.

2. When specific data was seen as desirable, a form for requesting and recording that information was useful. This permitted consistent collection and retrieval of data.

3. Forms that were very easily read and understood, both at Intake and for ongoing recording were valuable in obtaining more uniform data, and for ease in retrieving data when necessary.

4. A theoretical position viz a viz client services could be reflected in forms and recording procedures used, be that position behavioral, Transactional Analysis/Gestalt, or another approach.

5. Record-keeping procedures as a component of evaluative activity form a contimum from simple to complex.

6. A key person with interest in data gathering and an under- 
standing about its potential role in evaluation, made a difference In the quality and quantity of data gathered and the resultant product of useful information.

7. Development of a broad-based data gathering procedure was an evolutionary process. Inplementation of too much at once could precipitate staff resistance.

\section{Iiterature Search}

While the above conclusions were made from informally-gathered inforation, subsequent literature review supported the applicability of these conclusions to evaluative activity. This latter information lead to an understanding of the integral relationship that exists between the elements of evaluation. Key to this project was the function of record-keeping in management information system and the specific role that this system plays in program evaluation. A definitional overview of those key elements follows.

A well-prepared cllent file is not limited to a collection of demographic data, rather it represents the care provided to the client and responses to this care -- this feature of record-keeping delineates and confirms its fundamental place in evaluative activity. It is no longer expected that the therapist will depend upon memory to retain important details about clients. Now the client file serves as an Information bank avallable for many uses from quality assurance to examination of the course of therapy (Weed).

All staff benefit from accurate and well designed record-keeping. The secretary is saved expensive time she would spend retrieving details for demographic reports. The therapist, by recording more comprehensive 
initial information that certainly, with passage of time woid be dulled and reduced in specificity, will have dependable data. The client shares in this benefit along with the therapist because this same data can be used by both to appraise the client's progress in therapy (Grant, 1970). Good information permits the supervisor to better respond to shifts in caseloads. The assignments can be based not merely upon muber of clients but also the level of problem difficulty. Administrators can have avallable data which they can process with more assurance with regards to its reliability; and they can with greater ease retrieve more detail about clients without taking steps which would disrupt ongoing activity and wastefully consume time. For instance, a funding organization requests at the time of the annual report the number of clients served who were in crises. To collect this information from inadequately prepared records would prove impossible. The next step as an alternative to using the record would be disruptive in that the administrator would need individual reports from therapists. They, in response to such a request, mast stop seeing clients while, reviewing all the clients they served in the past year. With data gathered in areas staff find most useful all staff can use the data to assist their level of decision making.

The MIS, which is built upon agency record-keeping, permits a view of what is being done by the agency, assesses the relevance of the agency's actions to the community and clients' mental health needs, and determines the extent that the agency is attaining the goals it set for itself. The MIS draws this plcture by accepting, processing, storing, and presenting three types of information. For the authors' purposes, the three information categories were conceived of in the 
following manners

1. Environmental Information: serves to describe the client population and assess their needs. This assessment may include their resources. Such information includes the client's age, residence and other denographic information.

2. Internal Information: serves first to describe frequency and duration of contact between agency staff and clients. In addition, an attempt is made to describe the nature of the contact along dimensions other than frequency and time. Examples of this type of information are descriptions of the mamber, type, and severity of a client's problem, while specifying the approach used with this client and their response to this mode of intervention. Statements of impact upon the client can be developed from this type of information. Such statements are referred to as outcome evaluation.

Other sources of information important to making decisions about an agency's effectiveness ares records containing financial information, staff tine sheets, and agency contracts for service. In summary, mach of this information is readily available and usually gathered continuously. To be of value for evaluation the information must be gathered under uniform guidelines.

3. External Informations serves to reflect the output of an agency's program. Frequently, questionnaires, surveys, and comparative studies provide this category of information. The opinion survey initially proposed to the project is an example of this approach. The product of these techniques is open to interpretation because they are based upon statistical inferences. In contrast to the two previous categories of information, external information is not routinely collected 
and for this reason places unnecessary demand on agency resources. The most important point to make is that these approaches cannot be developed, nor used effectively, without a firmly established MIS of categories one and two (Mannio, 1978).

A usable MIS vitally expands and facliltates the work of program evaluation. MIS is a fundamental precondition to effective program evaluation. However, program evaluation is not bounded by MIS... MIS is not program evaluation, program evaluation is not MIS (Hagedorn, 1976, p. 73).

Definitions of program evaluation vary according to the perspective of the author. Suchman suggests that evaluation is a very scientific activity which tests the significance of knowledge (Suchman, 1967), while Stufflebeas relates evaluation to decision making (Stufflebeam, 1973). Patton in Utilization Focused Evaluation advocates for flexible, useful program evaluation (Patton, 1978). However, to the authors, the clearest and most logical definition of program evaluation is as follows,

Program evaluation is a systenatic set of data collection and analysis activities undertaken to detemine the value of a program to aid magement, program planning, staff training, public accountability and promotion. Bvaluation activities rake reasonable fudgments possible about the efforts, effectiveness, adequacy, efficiency, and comparative value of program options (Hagedorn, 1976). 
CHAPTER IV

PRES ENTING

While acquiring this information, regular feedback had been given to the executive director and the program director. At the conclusion of this phase of the project the task was to organize all the information acquired to present to the entire staff of SAFCS. This presentation was to serve two purposesi the primary purpose was to decide about changes to be made, and the secondary purpose was to begin to educate the staff about the general concept of program evaluation.

A continuum of possible choices (see Flgure 5) was designed as a way of visualizing and graphically presenting information. The range of this contimum began at a point just beyond the level of evaluative activity employed at SAFCS, to a point relatively distant, when viewing the mumber of changes required to reach it. The items on the continuum weres

1. Change in the physical organization of the files without addition of new data - this indicated such things as attachment of the face sheet to one side of the file, and placement of progress notes on a separate attached sheet.

2. Additional use of data already collected - this stage refers to activity such as tabulation and summary of existing data.

3. Addition of treatment mode, e.g., individual, group, to the records. 
Figure 5. Developmental contimul of record-keeping changes

Change in physical organization of files without the addition of new data

Additional uses of data already collected

Addition of treatment mode to records, e.g., individual, group

- Change in application form for readability, and ease of gathering information

- Collection of additional organized information, e.g., sheet with assessment of strengths, weakness, and problem

Regular recording

Individual contracting

Terminal objective for each cllent

Follow-up on terminal objective on regular basis

- Use of behavioral language

Goal-oriented evaluation procedure 
4. Change in intake form to one which could be more easily read including qualities which had been correlated with readability - e.8.. one question per line, large type, simple language, space to write (Knox, 1952, p. 108).

5. Collection of additional information, $. .8 .$, client strengths, goals of treatment - to indicate a possibility of moving to process and outcome evaluation.

6. Regular recording - this refers to recording at agreed upon intervals of time the clients' response to treatment.

7. Individual treatment contracts with clients - this denotes recording the agreement between client and therapist.

8. Terminal objectives with each client - with statements of this nature recorded in the client file both client and theraplst will find It possible to refer to this objective to reach a conclusion about what they accomplished.

9. Regular follow-up on terminal objectives - this indicates agreement upon a process and timing for follow-up on objectives. 10. Use of behavioral language in clients' records - this point upon the contimun is far from the simpler more feasible changes because it requires a fundamental change in attitude and approach to practice by SAFCS. Use of such language permits the ability to look for measurable categorles exclusive of diagnostic labels in use at SAFCS, and permits the reader to understand what has happened regardless of language commonly:used in his/her conceptual framework.

11. Goal-oriented evaluation procedure - this option indicates what was conceived of as a possible end-polnt for record-keeping 
change (Hardison, Shank, 1977).

The choices did not represent solutions, but a means to visualize and discuss alternatives; an aid to maiking a decision about what changes to make; and a commitment to what the staff saw as good choices for themselves and the agency at that time. The assumptions the authors made in creating this list were:

1. that it was best for staff to make a commitment to what they realistically felt they could do.

2. that any choices for change should be seen as part of a larger picture and dectied upon with that in mind.

3. that each alternative independently and/or in conjunction with any of the others could be a positive change in that direction suggested by the director in the initial request.

4. that most alternatives were open-ended enough to accommodate being approached in a variety of ways.

The commitment to these assumptions was a reflection of the belief that the authors' task was one of supporting agency staff and of building from where they already were.

Some further consideration in preparing for the presentation included an assessment of how the staff members individually might respond to the input; how a decision would be reached; what method of preparation would facilitate the desired type of involvement.

In considering the staff members individually, it seemed possible that there might be performance concerns about implementations of something new; that there might be theoretical disagreement about potential changes; that staff of less status might feel less free to give their 
ideas and opinions. On the other hand, it also seemed possible that potential changes could be seen as interesting or desirable by individual staff members (Zandu, 1961, pp. 543-548).

In considering how the decision would be made, past experience with this staff offered no reliable data.

In considering how to prepare for the presentation to increase the likelthood of staff involvement and reach consensus on the decision, the following techniques rere employed:

1. schedule the presentation meeting at a time when all staff could be present.

2. Inform them ahead of time, asking them to reserve that time, and stressing the desire for their involvement.

3. provide all staff with an agenda and information about the choices ahead of time in order for them to become familiar with them and think about them.

4. put items which would be discussed during the meeting on paper to be wall-mounted, thereby lessening the ownership of those 1deas.

5. put input from staff on wall-mounted paper, thereby recognizing and affirming input.

6. solicit input from those persons who were not offering it.

7. Iisten for and help people speak about their concerns.

8. be sensitive to timing, listening for whether people were prepared to make a decision, or whether they needed time to think about the choices, or whether they needed more information.

With this in mind the presentation to the staff was begun. Staff nembers spoke readily, sharing their opinions and ideas. The items 
on the contimuln were discussed. A distinction between a one-time process (such as an opinion survey), and an on-going process (such as

an evaluation procedure) became a long-range focus, and a decision issue. The meeting concluded with staff asking for more information about benefits and problems in three major areas of effort - changes in recording procedures, an opinton survey, or an evaluation; and for a week's time to process the input.

The requested information was provided to the staff. The format was a one-page outline designed to keep the focus basic, and to highlight some of the more commonly recognized issues in each of the areas. The information given was a reflection both of writing in the field and a pragmatic assessment of impact on this particular agency. The outline presented to the staff for purpose of this writing is titled "Benefits and Problems of Options for Evaluative Activity", and is presented in Figure 6.

One week after the original presentation, staff reassembled. Discussion and clarification of all options contimed. The staff gradually noved to a consensus affirmation of a long range end point of some form of client survey or evaluation. With that as reference point, they supported as a starting point, changes in the recordkeeping as it existed at that time. The most appropriate target was the application form. The staff supported designing a new, more readable intake form which would be checked for completeness, thus assuring a uniform pool of demographic information. Further they supported the implementation of a client assessment and progress sheet which would be the beginning of a data base on treatment process. 
F1gure 6. Benefits and Problems of Options for Evaluative Activity

I. Changes in Record-keeping System

A. Benefits

1. Saving of time spent retrieving information

2. El imination of unnecessary information

3. Clarity of forms would encourage response

4. Consistency in available information would be encouraged

5. Implementation of further systems would be eased

B. Problems

1. Expense of printing any new forms

2. Necessity of changing habits to incorporate new procedures

3. Any new information gathered would require time

4. Potential disagreement about information seen as necessary, or desirable to gather

II. Opinion Survey

A. Benefits

1. A means of reporting that services have been assessed

2. Gains information about client satisfaction

3. Information can be useful for management decisions

4. Change in recording procedures is not required

B. Problems

1. Because it's subjective, its credibility is questionable

2. May encounter client resistance

3. May interrupt usual procedures

4. If it is to be ongoing, will require staff time

III. Evaluation Procedure

A. Benefits

1. Administratively

a. Useful information for program plamning

b. Useful information for gramt and proposal writing

c. Clarifies actual service provided

2. Therapist-Client

a. Provides positive treatment focus

b. Makes assessment of termination more clear

c. Provides means to assess treatment effectiveness

d. Gives information to improve effectiveness

B. Problems

1. Time spent in decision making regarding the process

2. Time spent in training staff for consistency

3. Time spent in record-keeping

4. If behavioral language is used, dilemma about the "feeling" aspect of treatment

5. May create insecurity or performance anxiety 
29

The staff volunteered interest in reviewing potential forms and giving feedback. From that point on, initiation of the design phase began. 
CHAPTER V

DESIGN, IMPLEMENTATION, AND FOLLOW-UP

Thus the decision was made. Preparation for implementation Involved designing the new forms, and submitting them for practical testing by staff. Thls process occurred through informal brainstorming and feedback sessions with all, or portions, of the staff, and also reflected relevant reading, and examination of forms in use at othex agencies. Upon completing the designing, the agreed upon forms were implemented, and the focus of responsibility for their contimed use shifted primarily to the agency. Follow-up did occur, as did consultation with the staff about the results. At that point, total transition of responsibility occurred.

\section{Designing}

The design requirements of the new face sheet were that it be easily completed, readable, contain basically the same information as the previous form, and not exceed one page in length. The format presented was modeled after the face sheet at Elahan Mental Health Center.

A quick adaptation was from that form in order to show staff what a change light look like. The format was reworked by both clerical and clinical staff, in confunction with the authors, and on their own. Attention was focused on necessary information, and placement on the page. 
Several different areas of concern were addressed. Questions were tried in a varlety of arrangements in order to come up with a logical flow: Questions about similar matters were located together. For instance, information about income was placed at the bottom of the page, with space for the fee to be written just below It. This was done because the income figure was used in determining the fee. In questions with a range of answers, those categories used on the CLI form were included for ease in transfer of information. New information was also included. The previous form had not asked for work or school hours, or whether a phone call to the client's home or work was appropriate. Knowing this information was seen as Important. Sources of income also had not been previously gathered. However, it was becoming important to funding sources, and, so, was included. Additionally, questions about people living in the home, and referral source were presented more clearly than they had been.

Finally, two procedural additions were made. The first was to state on the face sheet the agency policy regarding confidentiality of client information. This was done for two reasons. First, to make that policy clearly known to the client; and second, to make known the agency's accountability to its own policy. The other change was to require a seperate face sheet for each person seen, whether as an Individual or as a member of a family. This was done in order to Insure that the same demographic data was available on all persons served by the agency, whether adult or child. In dealing with all of these modifications, the authors were careful to attend to those features which could make the new form easily readables large, 
readable type; clearly and simply stated questions; one question area per line; and ample space in which to write.

The only question about the final format was a concern that adhering to a left hand margin start for each question area would result in wasted space. However, staff quickly supported the improved appearance that resulted from setting the form up in a new way, and the 1ssue ended there.

The receptionist reported, after a week's trial, that the form was being well accepted by clients. By July 1, the staff had given final approval to the new face sheet design, and it was ready to be implemented. That design is displayed in reduced form in Figure ?.

Though more complex in purpose, and a greater departare from the previous recording systen, the intake/plan form was also the source of much interest by staff during the design phase. This form was to function as a replacement for the lower portion of the previous application form, and was to provide uniform coverage of specific areas of the assessment and treatment process.

The format proposed was adapted, primarily, from one in use at Yamh111 County Mental Health Center. The suggested categories on that form were: presenting problems; client background information; client strengths; cllent reaknesses; client goals and expectations; therapist's assessment; therapist's plan; In discussion, clinical staff indicated that many of the suggestions fade for inclusion from the Yambill form were areas that they were already concentrating on, but not recording. Their comments confirmed the utility of these categories. The rord "weakness" did draw nneasy feelings from staff. Much discussion cen- 
Figure 7. Face Sheet (reduction)

PLEASE FILL OUT ONE OF THESE FORMS FOR EACH PERSON WHO WILL BE A CLIENT. The information entered on this form will be treated confidentially and will not be released to unauthorized parties.

- Have you been to Family Counseling Service before? No $\square$ Yes $\square$ When

- Today's date

- Name

- Address

- Home phone Don't call $\square$ Work phone Zip

- Work or school hours

- Age

- Sex: Male $\square$ Female $\square$ Birthdate Bonth/Day / year /

- Education (Enter highest grade completed)

- Are you now in a school or training program Where

- Occupation Place of work

- Ethric background (Am. Indian, Asian, Black, Spanish Heritage, Cauc., Etc.)

- Marital Status: Single $\square$ Married $\square$ Divorced $\square$ Separated $\square$ widowed $\square$ other

- How did you find cut about our service? (newspaper, phone book, Friend, relative, doctor, etc.

- Please list the people currently living in your hame:

\begin{tabular}{|c|c|c|c|c|c|}
\hline Name & $\begin{array}{l}\text { Relation } \\
\text { to client }\end{array}$ & Sex & Age & $\begin{array}{l}\text { School or } \\
\text { Place of Work }\end{array}$ & Birthdate \\
\hline & & & & & \\
\hline & & & & & \\
\hline & & & & & \\
\hline & & & & & \\
\hline & & & & & \\
\hline & & & & & \\
\hline & & & & & \\
\hline & & & & & \\
\hline
\end{tabular}

- Check off all sources of incone: Jobs $\square$ Social Security $\square$ Public Assistance $\square$ Retirement $\square$ Unemployment comp. $\square$ child Support $\square$ Other

- Family's total monthly incane before deductions

- How many persons does this support Therapist's name 
tered around the content the category was seeking, and while thers was unanimity about tha importance of recording that, there was not agreement about what to title 1t. "Problem areas" was suggested, as was "areas of concern". Finally, the decision to leave it as stated was made. With reference to the previous category asking for "strengths", the thinking expressed, was that, as a pair, they were acceptable. In addition to the Yamhill categories, others were suggested. Clintcal staff wanted "physician" and "medication" to be included. In the case of a client transfer within the agency, this information would be passed on verbally. Staff felt that recording it provided more assurance that it would be known when needed. The mode of treatment, whether individual, couple, family, or group was also new. Finally, when asked how they wished to be known on the form, whether worker, counselor or therapist, they unanimously responded, "therapist". The agreed upon format went into a period of trial usage and the feedback was positive. The categorles were open-ended enough to allow for uniqueness in therapist style. The time required to complete the form was acceptable. The prime issue which emerged was definitional, with therapists asking one another about the content they designated for each category: A problem emerged with regard to the category asking for "client strengths". The clinical staff admitted to being umused to articulating that content, and feeling, at first, that they were seeing a new perspective on clients.

The form as it exists today (a reduced copy is presented in Figure 8), was decided upon by a process of research, discussion, and experimentation. The categorles have been given some uniformity through 
Figure 8. Intake and Plan (reduction)

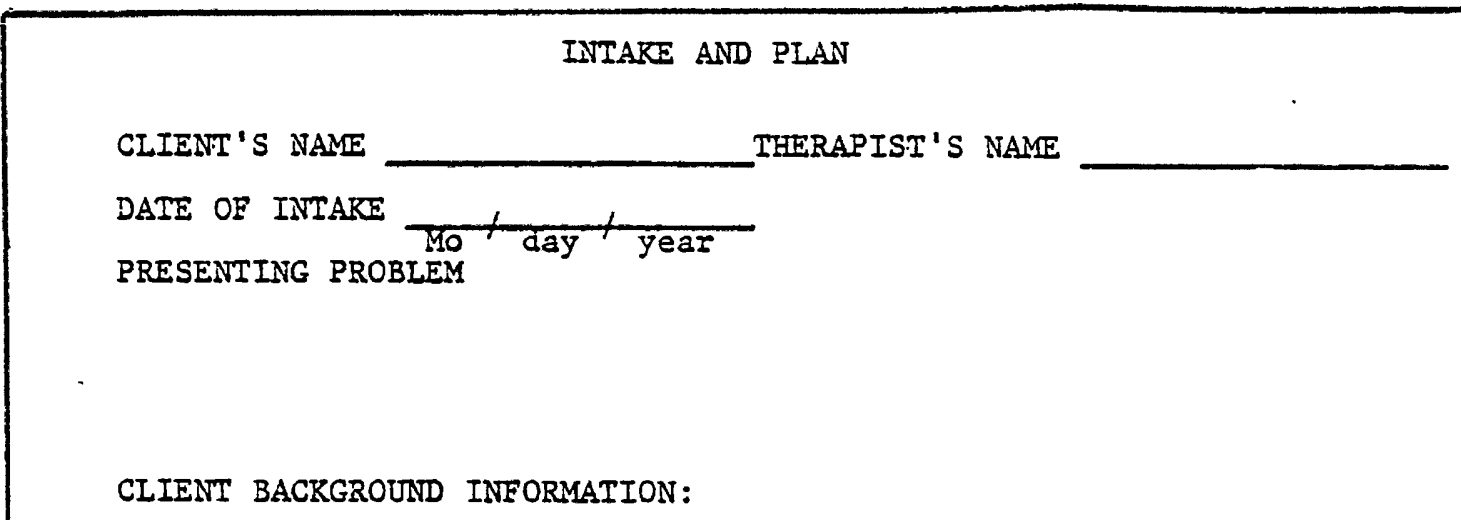

CIIENT STRENGTHS:

CLIENT WEAKNESSES :

CLIENT GOALS \& EXPECTATIONS:

THERAPIST"S ASSESSMENT

THERAPIST"S PLAN (include contracts)

MODE OF THERAPY

Group

Family

Individual

Couple

Other

Medication Physician 
use and feedback.

The therapist begins completing the form with a statement of the problem from the viewpolnt of the therapist and client, and includes a brief assessment of the client's situation. Historical information pextinent to the present problen would generally include past features of the client's experience which have the greatest impact upon the current situation. The resources the client has within himself or herself, and within their current life situation, are listed as strengths that may be employed by the client in making a change. Particuiar areas of concern are listed as weaknesses. In keeping with the orientation of the agency, a statement is made about what the cllent wants and expects to gain from therapy. The therapist follows that with his or her assessment of the situation; The therapist's plan is a formulation of the treatment that will occur, with attention paid to the ordex in which it my proceed. Whether the client is taking any mood-altering medication is indicated, as well as the prescribing physician. Finally, the therapist indicates the mode of treatment. Having done that, the form is completed.

\section{IMPLEMENUATION}

Once the design phase was over, the forms had been tested, feedbacis had been given, and incorporated, the actual implemantation occurred. July 1 was the target date because it began the new fiscal year, and seened a particularly appropriate tine to introduce a means to begin to modify the available data.

For the new face sheet, 1mplenentation happened in two ways. First, all clients new to the agency after July 1 filled out the new 
form: Second, 2.1 on-going clients who had begun prior to July 1 were asked to fill out a new face sheet. The result of the process would be to have current face sheets on all current clients.

The intake/plan form was instituted with new clients in the same manner! With on-going clients its implementation was problematical. Whereas demographic data could be recounted from a prior time, or given as it existed at that moment, treatment data posed a pecullar problem. To asis therapists to write up a plan as they recalled the Initial contact was questionable. To create a new intake/plan for an on-going client was a possiblilty. Howevex, because they had been in treatment for varying lengths of time, the data generated would be questionable. Staff talked and thought about this dilemia, finally deciding to have intake/plan forms only for clients new to the agency after July 1.

The design and implementation was a step by step process which involved many discussions with staff, trial proposals, feedback, and, finally resulted in the creation and implementation of forms which the staff felt pleased with:

\section{Follow-up}

The process of monitoring the implementation was carried out by two reviews of client files, and by informal contact with the staff during the remainder of the calendar year.

The findings of the first review on the files of clients new since July 1, was in marked contrast to the findings of the November, 1977 review of the files. The new examination indicated that face sheets were being filled out completely. Therapists rere now recording in 
anple, legible form, and provlding detail about their client's circumstances: All categories of the intake/plan form were uniformly completed, with occasional exceptions of the section indicating physician's name and medication.

Therapists' reactions were positive in nature about the new form. The receptionist stated that with the new face sheet, clients approached her only rarely with questions, and that information was easier to retrieve.

It was the hope of the authors that within two months of implementation, or September 1, there would be a significant enough number of forms utilized to evaluate their usefulness. The time of implementation coincided with a decline in clients requesting service, and a drop in hours of client service given due to a smaller staff. The result was the necessity for a longex period of follow-up involvement. The first review was conducted at the end of September. At this time there had been twelve new clients.

During the final tally of client files in December, a further difficulty arose. This time files of all clients were surveyed. Forty percent were found to be lacking both a new face sheet and an Intake/plan. When clinical staff were questioned about these cases they explained that the clients had not been to the agency since before July 1, but no action had been taken on their files. This pointed out a lack of agreement among clinical staff about definitions of open cases and terminations, and the lack of a policy about regularly purging files. This was pointed out to them, with the information that it would affect their data base, and left to them for resolution. When only the cases that were "open" were considered in the December 
review, the utilization results were positive. Thus, the difficulties which arose were not of sufficient magnitude to counter what has been a positive step for the staff of SAFCS in implementing change in their record-iseeping system. Primarily, they pointed out that the nature of change involves continual working out of-problem areas as they emerge. 


\section{CHAPTER VI}

\section{CONCLUSION}

The improvement of a record-keeping system to provide more easily and uniformly available data, and, in the future, to support the performance of process and outcome evaluation was the project's objective. This was accomplished, and its achievement will be discussed. Within this formal objective there are two broad factors which, in retrospect, were germane to its attainment. The first is the role chosen by the authors in relationship to agency staff. The second is the parameters established by the authors for a record-keeping system.

The evaluator/consultant role assumed by the authors called for soliciting agency needs, researching options, facilitating staff input, feedback, and decision-maiking, while leaving the major responsibility for implementation and utilization to the agency. By this process, the staff was able to have avallable for their consideration information which was particularly suited to their needs. They were able to consider it in light of their unique situation, and able to invest in the decision made, since they would be its inplementors.:

The second factor clearly relates to form utilization. In researching alternative models and in designing the implemented model, parameters were specified which provided guidelines. Information gathered heeded to be easily retrivable, utilized by staff and/or 
funding sources, and kept to a minimum. The amount of staff time required to collect information was a concern. The attainment of the objective, the improvement of a recordkeeping system, was facllitated by the actualized evaluator/consultant role. The concreteness of the flnalized task allowed the authors to define boundaries for cost, time, and needs, and then proceed with a minimum of distractions. The authors" primary neasurement of success has been the agency's utilization of the improvements. Since evaluation is a relatively new concept to social services, smalI private agencies are often just beginning to address the issue. Record-keeping is the basis for this concept and a necessary preIlminary step: The authors have assisted Salem Area Family Counseling Service in beginning to recognize the necessity for a comprehensive system by implementing this intial step. 
Benne, Kenneth. "Democratic Ethics and Human Engineering," The Planning of Change. Warren Bennis, Kenneth Benne, and Robert Chin (ed.). New Yoris! Hold, Rinehart and Winston, 1961. pp. 141-148.

Clarkson, Quentin, Nancy Koroloff and Wayne Newberger. Readings in Program Evaluation. Portland, Oregon: Portland State University, 1977.

Grant, Richard L., and Bary M. Maletsky. "A Scientific Approach to Psychiatric Record-keeping," presented at The American Psychiatric Association Meeting, San Francisco, California, May 15, 1970.

Hegedom, Homer, Kenneth Beck, Stephen Newbert and Stanley Werlin. A Working Mamual of Simple Program Evaluation Techniques for Community Mental Health Centers. Rockville, Maryland, DHEW, 1976.

Hardison, Jim and Steve Shank. G.O,R,K, Salem, Oregons Mental Health Division, 1977.

Hoshino, George, "Social Services: The Problems of Accountability," Social Service Revien. Vol. 47, No.:3, Sept.,1973, pp. 373-383.

James, Murial and Dorothy Jongeward. Born to Win Reading, Massachusettsi Addison-Wesley Publishing Co., 1973.

Kiresuk, Thomas and Geoffrey Garwick. "Basic Goal Attainment Scaling Procedures" "Social Work Processes. Beulah Compton and Burt Galaway (ed.), IIIInoisi Dorsey Press, 1975.

Xiresuk, Thomas J. and Robert E. Sherman. "Goal Attainment Scaling: A General Method for Evaluating Comprehensive Community Mental Health Programs," Journal of Community Mental Health. Vol. 4, December, 1968, pp. 443-453.

Knox, M: Frank: Design and Control of Business Forms: New York: McGraw Hill Book, 1952.

Lew1n, Kurt. "Quasi-Stationary Soclal Equilibria and the Problem of Permanent Change;" The Planning of Change. Warren Bennis, Kenneth Benne, and Robert Chin (ed.). New York: Holt, Rinehart and Winston, 1961, pp. 235-238. 
Lippitt, Romald. "Dimensions of the Consultant's Job," The Planning of Change. Warren Bennis, Kenneth Benne, and Robert Chin (ed.). New York? Holt, Rinehart, and Winston, 1961, pp. 156-162.

Iund, Donald A. "Mental Health Program Evaluation; Where You Start?" Journal of Evaluation and Program Planning. Vol. 1, 1978, pp.31-40.

Mannio, Fortune V. and Berya W. MacLennan. Monitoring and Evaluating Mental Health Consultation and Education Services. Rocikille, Maryland, NIMH, 1978.

Mazur, P. Walter. The Problem Orlented System in the Psychiatric Hospital, A Complete Mamual for Mental Health Professionals. Garden Grove, California: Trainex Corp., 1974.

Martens, Wilma M. and Elizabehth Holmstrup. "Problem Orlented Recording," Social Casework. Vol. 55, Nov. 1974, pp. 554-561.

McIntyre, Marguerite, C. Clifford Attikisson and Timothy Keller. "Components of Program Evaluation in Comminity Mental Health Centers," Resource Materials for Community Mental Health Program Evaluation (2nd ed.). William Hargraves, C. Clifford Attkisson, and James Sorenson (ed.). Rockville, Maryland: U.S. DHEW, 1977.

Oregon District 3 Statistical Data Base 1978. Salem, Oregon Mid Willamette Valley Council of Governments, May, 1978.

Patton, Michael. Utizization Focused Evaluation. Beverly Hills, California: Russell Sage Foundation, 1978.

Sanders, Inwin. "Professional Roles in Planned Change," Readings in Community Organization Practice, Ralph Kramer and Harry Specht (ed.). New Jersey: Prentice-Hall, Inc., 1969, pp. 269-278.

Scales, John E. "A Psychiatric POMR for Use by a Multidisciplinary Team " Hospital and Communtty Psychiatry. Vol. 26, June, 1975, pp. 371-373.

Sorenson, James E., Williail A. Hargraves and Clifford C. Attkisson (ed.). Resource Materials for Community Mental Health Program Evaluation. Rockville, Marylands DHEW, 1977.

Suchman, Edward A. Evaluative Research Principles and Practices in Public Service and Social Action Programs. New York: Russell Sage Foundation, 1967.

Stufflebeam, Daniel I. "Educational Evaluation and Decision Making," Educational Evaluation: Theory and Practice. Worther Blainer, James R. Sanders, Belmont, Californial Wadsworth Publishing Co., 1973. 
Weed, Lawerence I. Medical Records, Medical Education, and Patient Care. New York: The Press of Case Western Reserve University. 1969.

Weiss, Carol. "Between the Cup and the IIp," Resource Materials for Community Mental Health Program Evaluation:(2nd ed.). William Hargreaves, C. Clifford Attjkisson, and James Sorenson (ed.). Rockville, Marylend: U.S.DHEW, 1977 .

Zandu, AIvin. "Resistance to Change- Its Analysis and Prevention," The Planning of Change. Warren Bennis, Kenneth Benne, and Robert Chin (ed.). New Yorks Holt, Rinehart and Winston, 1961. pp. 543-548: 